\title{
Sexual Dimorphism in Mesiodistal and Bucolingual Tooth Dimensions in Chilean People
}

\author{
Dimorfismo Sexual en las Dimensiones Mesiodistales y Bucolinguales \\ de las Piezas Dentarias en Individuos Chilenos \\ Iván Suazo Galdames; Mario Cantín López; Bernarda López Farías; Catherine Sandoval Marchant; \\ Sebastián Torres Muñoz; Patricio Gajardo Rojas \& Marcelo Gajardo Rojas
}

SUAZO, G. I.; CANTÍN, L. M; LÓPEZ, F. B.; SANDOVAL, M. C.; TORRES, M. S.; GAJARDO, R. P. \& GAJARDO, R. M. Sexual dimorphism in mesiodistal and bucolingual tooth dimensions in Chilean people. Int. J. Morphol., 26(3):609-614, 2008.

SUMMARY: The study investigates the presence of sexual dimorphism in the size of the permanent teeth among Chilean individuals. Mesiodistal and bucolingual diameters were measured in the teeth of 150 patients between 18 and 24 years old, 67 males and 83 females (excluded were third molars and pieces with large cavities and fillings). The largest were found in males; the differences in mean bucolingual diameters with $\mathrm{p}<0.05$ were observed in pieces $1.1,1.2,1.3,1.6,1.7,2.6,3.3,4.1,4.2$, and 4.5 ; and with $\mathrm{p}<0.01$, the relevant pieces were to 4.4 and 4.7. With regard to mesiodistal dimensions, the only significant difference $\mathrm{p}<0.05$ was found in piece 1.2 . These results show that sexual dimorphism can be found in all group teeth.

KEY WORDS: Tooth dimensions; Sexual dimorphism; Dental crown; Sex characteristics.

\section{INTRODUCTION}

Identification of human remains during mass disasters is hindered by the state of the soft tissue. With relevant expertise, it is carried out on bones and teeth (Ndiokwelu et al., 2003; Slaus et al., 2007).

For this reason, forensic dentistry has played an important, often crucial, role in the identification of victims of mass disasters (Van der Kuijl \& Van der Pols, 1995; Blau et al., 2006), being useful not only in disasters caused by nature but also under circumstances that bring massive tragedies (Ermenc \& Rener, 1999), tsunami (Dawidson, 2007; Petju et al., 2007), fire (Valenzuela et al., 2000), incineration after a car accident (Martin de las Heras et al., 1999), air crashes (Brannon et al., 2003; Bux et al., 2006), and rail disasters (Solheim et al., 1992), among others.

The dentition is often preserved, even when the bony structures of the body are destroyed because of its physical characteristics and the protection it gets from the bone jaw. It has the ability to resist, better than any other skeletal structure, the destructive action of the medium in which they are found (Toribio \& Soto, 1995). For this reason, the use of dental morphology to determine sexual dimorphism is a procedure established in anthropological and biological studies (Edgar, 2005).

The existence of sexual dimorphism in permanent teeth is a known phenomenon, as observed in several investigations (Jensen et al., 1957; Kondo \& Townsend, 2004). This behavior morphogenetically determined that the shape and dimensions of the tooth are fairly stable and has been seen as a determining factor in providing sexual dimorphism in skeletal remains, which is required for forensic identification purposes (Rodríguez, 2004).

The variation in odontometry is especially important to determine the influence of sexual dimorphism on the size of the teeth (Ruiz, 2004). The presence of significant differences between the upper canine and the lower lateral incisor has been described; the mesiodistal diameter is greater for both pieces in males than in females (PettenatiSoubayroux et al., 2002).

The size of the teeth is of great importance not only to indicate the different activities related to the occlusion or determine the frequency of dento-tooth anomalies applied 
to the orthodontic treatment, but also to establish sexual dimorphism (Buthz \& Ehrhardt, 1938). This, therefore, will have a great significance in forensic medicine. Because of this, the knowledge of coronary dimensions for the identification of sex when skeletons are found becomes relevant, especially when anatomical parameters are not reliable for identifying a particular subject. This would decrease getting the number of wanted individuals to a probability of $50 \%$, which, together with information obtained from a clinical registration document (done during rehabilitative treatment for each patient), can result in a more accurate way of identifying the person sought.
Gómez (2005) analyzed a sample of 86 adult Colombians and determined increased sexual dimorphism in the canines. Similar results have been obtained by various researchers (Evan, 1994; Rodríguez, 2003).

Most of the studies have been conducted by measuring the mesiodistal and bucolingual diameters in permanent teeth. Kondo \& Townsend included temporal molar teeth in a study demonstrating that it was also possible to identify sexual dimorphism in them.

We analyze the presence of sexual dimorphism in mesiodistal and bucolingual size in the crowns of permanent teeth.

Table I. Statisticians descriptive mesiodistal and bucolingual diameters of the maxillary teeth of 150 males and females between 18 and 24 years.

\begin{tabular}{|c|c|c|c|c|c|c|c|c|}
\hline \multirow{4}{*}{$\begin{array}{l}\text { Tooth } \\
1.7\end{array}$} & \multirow{4}{*}{$\begin{array}{l}\text { Gender } \\
\text { Male } \\
\text { Female }\end{array}$} & \multirow{4}{*}{$\begin{array}{l}\text { N } \\
66 \\
77\end{array}$} & \multicolumn{3}{|c|}{ Mesiodistal } & \multicolumn{3}{|c|}{ Bucolingual } \\
\hline & & & Mean & SD & \multirow{3}{*}{$\begin{array}{l}\text { Sig. } \\
.234\end{array}$} & \multirow{3}{*}{$\begin{array}{l}\text { Mean } \\
11.3859 \\
10.9927\end{array}$} & \multirow{3}{*}{$\begin{array}{l}\text { SD } \\
.68071 \\
.63676\end{array}$} & \multirow{3}{*}{$\begin{array}{l}\text { Sig. } \\
.001 *\end{array}$} \\
\hline & & & 10.0062 & .74872 & & & & \\
\hline & & & 9.8291 & .98408 & & & & \\
\hline \multirow[t]{2}{*}{1.6} & Male & 62 & 10.6784 & .73422 & \multirow{2}{*}{.093} & 11.4080 & .77397 & \multirow{2}{*}{$.010^{*}$} \\
\hline & Female & 79 & 10.4761 & .68209 & & 11.1157 & .58303 & \\
\hline \multirow[t]{2}{*}{1.5} & Male & 62 & 7.0965 & .90884 & \multirow{2}{*}{.420} & 9.5805 & .70600 & \multirow{2}{*}{.343} \\
\hline & Female & 79 & 6.9629 & 1.01901 & & 9.4654 & .72221 & \\
\hline \multirow[t]{2}{*}{1.4} & Male & 55 & 7.0560 & .70770 & \multirow{2}{*}{.259} & 9.5162 & .78887 & \multirow{2}{*}{.119} \\
\hline & Female & 71 & 6.9172 & .66066 & & 9.2907 & .79735 & \\
\hline \multirow[t]{2}{*}{1.3} & Male & 67 & 8.0488 & .62420 & \multirow{2}{*}{.177} & 8.3651 & .88795 & \multirow{2}{*}{$.026^{*}$} \\
\hline & Female & 82 & 7.9113 & 60871 & & 8.0587 & .78130 & \\
\hline \multirow[t]{2}{*}{1.2} & Male & 66 & 7.1021 & .70753 & \multirow{2}{*}{$.024 *$} & 6.719 & .7851 & \multirow{2}{*}{$.018^{*}$} \\
\hline & Female & 81 & 6.8502 & .63383 & & 6.400 & .8197 & \\
\hline \multirow[t]{2}{*}{1.1} & Male & 66 & 8.6927 & .73973 & \multirow{2}{*}{.071} & 7.1748 & .74135 & \multirow{2}{*}{$.019^{*}$} \\
\hline & Female & 83 & 8.4707 & .74266 & & 6.9022 & .65968 & \\
\hline \multirow[t]{2}{*}{2.1} & Male & 66 & 8.6939 & .64982 & \multirow{2}{*}{.199} & 7.1892 & .75498 & \multirow{2}{*}{.346} \\
\hline & Female & 83 & 8.5437 & .74805 & & 7.0743 & .72853 & \\
\hline 2.2 & Male & 67 & 6.9455 & .57821 & & 6.6487 & .74567 & \\
\hline & Female & 81 & 6.8504 & .75118 & .397 & 6.4173 & .81136 & .074 \\
\hline 2.3 & Male & 67 & 7.9243 & .61450 & & 8.128 & .9701 & \\
\hline & Female & 83 & 7.8360 & .67230 & .407 & 7.940 & .7563 & .185 \\
\hline 2.4 & Male & 54 & 7.2283 & .60851 & 174 & 9.448 & .8720 & 111 \\
\hline & Female & 71 & 7.0800 & .59415 & .174 & 9.210 & .7856 & .111 \\
\hline 2.5 & Male & 62 & 6.9490 & .70100 & & 9.5540 & .91451 & \\
\hline & Female & 79 & 6.7851 & .71388 & .175 & 9.3352 & .88877 & .154 \\
\hline 2.6 & Male & 62 & 10.3897 & .88912 & & 11.4069 & .85932 & \\
\hline & Female & 81 & 10.3052 & .78168 & $.54 /$ & 11.1223 & .73839 & $.033^{\circ}$ \\
\hline 2.7 & Male & 66 & 9.8373 & .82406 & & 11.4338 & .94515 & \\
\hline & Female & 80 & 9.8548 & .80418 & .891 & 11.1762 & .67659 & .058 \\
\hline
\end{tabular}

* The statistical significance was found with a p-value $<0.05$. 


\section{MATERIAL AND METHOD}

A descriptive study was conducted through crosssectional anthropometry indirectly. Without random sampling, for convenience, were recruited 150 patients between 18 and 24 years of age (mean 21.5 years, SD 1.31), 67 males and 83 females. Plaster models of the maxillary and mandibular arches from alginate impressions in these patients were obtained.

The models were numbered according to sex of the individual. The measurements excluded teeth with extensive cavities, fillings involving free and/or proximal surfaces, pieces with position anomalies, and third molars.
Using a digital caliper $(0.01 \mathrm{~mm})$, we determined mesiodistal and vestibulolingual diameters of each permanent tooth following procedures described by Moorrees \& Reed (1964).

The measurements were made by two operators, "blinded" as to the sex of the individual information corresponding to the model, and through the method of remeasurement, a random sample was calculated to find interobserver correlation coefficient.

Using the SPSS 11.5 software for Windows, descriptive statistics were obtained from the sample. The statistical significance of differences in mean in mesiodistal and bucolingual diameters between males and females was calculated using the $t$ test for independent samples with $p<0.05$.

Table II. Statisticians descriptive mesiodistal and bucolingual diameters of the mandibular teeth of 150 males and females between 18 and 24 years.

\begin{tabular}{|c|c|c|c|c|c|c|c|c|}
\hline \multirow{3}{*}{$\begin{array}{l}\text { Tooth } \\
1.7\end{array}$} & \multirow[b]{2}{*}{ Gender } & \multirow[b]{2}{*}{$\mathrm{N}$} & \multicolumn{3}{|c|}{ Mesiodistal } & \multicolumn{3}{|c|}{ Bucolingual } \\
\hline & & & Mean & SD & Sig. & Mean & $\mathrm{SD}$ & Sig. \\
\hline & Male & 66 & 10.0062 & .74872 & \multirow{2}{*}{.234} & 11.3859 & .68071 & \multirow{2}{*}{$.001 *$} \\
\hline & Female & 77 & 9.8291 & .98408 & & 10.9927 & .63676 & \\
\hline \multirow[t]{2}{*}{1.6} & Male & 62 & 10.6784 & .73422 & \multirow{2}{*}{.093} & 11.4080 & .77397 & \multirow{2}{*}{$.010 *$} \\
\hline & Female & 79 & 10.4761 & .68209 & & 11.1157 & .58303 & \\
\hline \multirow[t]{2}{*}{1.5} & Male & 62 & 7.0965 & .90884 & \multirow{2}{*}{.420} & 9.5805 & .70600 & \multirow{2}{*}{.343} \\
\hline & Female & 79 & 6.9629 & 1.01901 & & 9.4654 & .72221 & \\
\hline \multirow[t]{2}{*}{1.4} & Male & 55 & 7.0560 & .70770 & \multirow{2}{*}{.259} & 9.5162 & .78887 & \multirow{2}{*}{.119} \\
\hline & Female & 71 & 6.9172 & .66066 & & 9.2907 & .79735 & \\
\hline \multirow[t]{2}{*}{1.3} & Male & 67 & 8.0488 & .62420 & \multirow{2}{*}{.177} & 8.3651 & .88795 & \multirow{2}{*}{$.026^{*}$} \\
\hline & Female & 82 & 7.9113 & .60871 & & 8.0587 & .78130 & \\
\hline \multirow[t]{2}{*}{1.2} & Male & 66 & 7.1021 & .70753 & \multirow{2}{*}{$.024 *$} & 6.719 & .7851 & \multirow{2}{*}{$.018^{*}$} \\
\hline & Female & 81 & 6.8502 & .63383 & & 6.400 & .8197 & \\
\hline \multirow[t]{2}{*}{1.1} & Male & 66 & 8.6927 & .73973 & \multirow{2}{*}{.071} & 7.1748 & .74135 & \multirow{2}{*}{$.019 *$} \\
\hline & Female & 83 & 8.4707 & .74266 & & 6.9022 & .65968 & \\
\hline \multirow[t]{2}{*}{2.1} & Male & 66 & 8.6939 & .64982 & \multirow{2}{*}{.199} & 7.1892 & .75498 & \multirow{2}{*}{.346} \\
\hline & Female & 83 & 8.5437 & .74805 & & 7.0743 & .72853 & \\
\hline \multirow[t]{2}{*}{2.2} & Male & 67 & 6.9455 & .57821 & \multirow{2}{*}{.397} & 6.6487 & .74567 & \\
\hline & Female & 81 & 6.8504 & .75118 & & 6.4173 & .81136 & .074 \\
\hline 2.3 & Male & 67 & 7.9243 & .61450 & & 8.128 & .9701 & \\
\hline & Female & 83 & 7.8360 & .67230 & .407 & 7.940 & .7563 & .185 \\
\hline 2.4 & Male & 54 & 7.2283 & .60851 & 174 & 9.448 & .8720 & 111 \\
\hline & Female & 71 & 7.0800 & .59415 & $.1 / 4$ & 9.210 & .7856 & .111 \\
\hline 2.5 & Male & 62 & 6.9490 & .70100 & & 9.5540 & .91451 & \\
\hline & Female & 79 & 6.7851 & .71388 & .175 & 9.3352 & .88877 & .154 \\
\hline 2.6 & Male & 62 & 10.3897 & .88912 & & 11.4069 & .85932 & \\
\hline & Female & 81 & 10.3052 & .78168 & .547 & 11.1223 & .73839 & $.033^{*}$ \\
\hline 2.7 & Male & 66 & 9.8373 & .82406 & 897 & 11.4338 & .94515 & 058 \\
\hline & Female & 80 & 9.8548 & .80418 & .891 & 11.1762 & .67659 & .058 \\
\hline
\end{tabular}

* The statistical significance was found with a p-value $<0.05, * * \mathrm{p}<0.01$ 


\section{RESULTS}

Most of the mesiodistal and bucolingual dimensions of the maxillary and mandibular tooth crowns were higher in males, with the exception of mesiodistal diameters in teeth $2.7,3.6,3.5$, and 3.1 and the bucolingual diameters of 3.7, 3.2, and 4.6, which were found higher in females. These differences, however, were not significant.

As to differences in bucolingual diameter, they were significantly higher in males with $\mathrm{p}<0.05$ for teeth $1.1,1.2$, $1.3,1.6,1.7,2.6,3.3,4.1,4.2$, and 4.5 and, at $\mathrm{p}<0.01$, for teeth 4.4 and 4.7. With regard to the mesiodistal dimensions, the only significant difference $(\mathrm{p}<0.05)$ was found in tooth 1.2 this was higher in males than in females.

Table I shows the descriptive statistics and significance of differences in the mesiodistal and bucolingual diameters of the maxillary teeth. In Table II are observed the results for the mandibule teeth. We found a high correlation between the observations, $\mathrm{k}=0.98$.

\section{DISCUSSION}

The presence of sexual dimorphism in the size of the temporary and permanent teeth is a fact welldocumented in humans and primates (Garn et al., 1967; Garn et al., 1977; Scott \& Turner, 1997; Kondo et al., 1998; Kondo \& Townsend; Kondo et al., 2005; TeschlerNicola, 1992; Wood et al., 1991).

Most studies indicate that the mandibule canine is the tooth that presents greater dimorphism, followed by the first and second maxillary molars (Acharya \& Mainali, 2007; Kondo et al., 1998; Kondo et al., 2005; Ling \& Wong, 2006). In our work, the significant differences were found mainly in bucolingual diameters, but theyincluded various teeth of all dental groups, the largest being found in teeth 4.4 and 4.7 , these results are similar to those reported by Ruiz in a Chilean population similar to this study, which reinforces the arguments (Alt et al., 1998) that changes in dental dimensions are influenced by ethnic factors.

It is worth noting that no significant differences in the mesiodistal diameter of the analyzed teeth were found; Stanley et al. (1966) described the presence of sexual dimorphism in mesiodistal diameter of permanent teeth among Caucasians, but that the dimorphism percentage was higher in terms of bucolingual dimensions.
SUAZO, G. I.; CANTÍN, L. M; LÓPEZ, F. B.; SANDOVAL, M. C.; TORRES, M. S.; GAJARDO, R. P. \& GAJARDO, R. M. Dimorfismo sexual en las dimensiones mesiodistales y bucolinguales de las piezas dentarias en individuos chilenos.Int. J. Morphol., 26(3):609-614, 2008.

RESUMEN: Se investiga la presencia de dimorfismo sexual en las dimensiones de las piezas dentarias permanentes, en individuos chilenos. Se midieron los diámetros mesiodistales y bucolinguales de las piezas dentarias de 150 pacientes, de entre 18 y 24 años de edad, 67 hombres y 83 mujeres, se excluyeron los terceros molares y las piezas con caries y obturaciones extensas. Las mayores dimensiones se encontraron en hombres, diferencias significativas en los diámetros bucolinguales con $\mathrm{p}<0.05$ resultaron en las piezas 1.1, 1.2, 1.3, 1.6, 1.7, 2.6, 3.3, 4.1, 4.2 y 4.5 y con $\mathrm{p}<0.01$ para las piezas 4.4 y 4.7. Con respecto a las dimensiones mesiodistales, la única diferencia significativa con $\mathrm{p}<0.05$ se encontró en la pieza 1.2. Estos resultados muestran que es posible encontrar dimorfismo sexual en todos los grupos dentarios.

PALABRAS CLAVE: Dimensiones dentales; Dimorfismo sexual; Corona Dental; Características sexuales.

\section{REFERENCES}

Acharya, A. B. \& Mainali, S. Univariate sex dimorphism in the Nepalese dentition and the use of discriminant functions in gender assessment. Forensic Sci. Int., 173(1):47-56, 2007.

Alt, K. W.; Rösing, F. W. \& Teschler-Nicola, M. Dental Anthropology. Fundamentals, Limits and Prospects. New York, Springer Verlag Wien, 1998.

Blau, S.; Hill, A.; Briggs, C. A. \& Cordner, S. M. Missing persons-missing data: the need to collect antemortem dental records of missing persons. J. Forensic Sci., 51(2):386-9, 2006.

Brannon, R. B.; Morlang, W. M. \& Smith, B. C. The gander disaster: dental identification in a military tragedy. $J$. Forensic. Sci., 48(6):1331-5, 2003.

Buthz, R. M. \& Erhrhardt, R. M. Nossintchouk, Manuel d'odontologie médico-légale. Paris, Masson, 1938.

Bux, R.; Heidemann, D.; Enders, M. \& Bratzke, H. The value of examination aids in victim identification: a retrospective study of an airplane crash in Nepal in 2002. Forensic Sci. Int., 164(2-3):155-8, 2006. 
Dawidson, I. The dental identification of the Swedish Tsunami victims in Thailand. Forensic Sci. Int., 169(1):S47-48, 2007.

Edgar, H. J. H. Prediction of social race category using characteristics of dental morphology. J. Forensic Sci., 50(2):269--73, 2005

Ermenc, B. \& Rener, K. Possibilities for dental identification in the case of mass disaster in Slovenia. Forensic Sci. Int., 103(1):S67-75, 1999.

Evan, I. G.Better dead than red.Ther. Immunol., 1(6):343-8, 1994.

Garn, S. M.; Lewis, A. B.; Swindler, D. R. \& Kerewsky, R. S. Genetic control of sexual dimorphism in tooth size. $J$. Dent. Res., 46(5):963-72, 1967.

Garn, S. M.; Cole, P. E.; Wainwright, R. L. \& Guire, K. E. Sex discriminatory effectiveness using combinations of permanent teeth. J. Dent. Res., 56(6):697, 1977.

Gómez, M. J. Estudios sobre somatología y variabilidad poblacional en Colombia. Revista Exhumar, 2:13-25, 2005.

Jensen, E.; Kai-Jen Yen, P.; Moorrees, C. F. \& Thomsen, S. O. Mesiodistal crown diameters of the deciduous and permanent teeth in individuals. J. Dent. Res., 36(1):3947, 1957.

Kondo, S.; Funatsu, T.; Wakatsuki, E.; Haung, S. T.; Change, S. Y. \& Shibasaki, Y. Sexual dimorphism in the tooth crown dimensions of the second deciduous and first permanent molars of Taiwan Chinese. Okajimas Folia Anat. Jpn., 75(5):239-46, 1998.

Kondo, S. \& Townsend, G. C. Sexual dimorphism in crown units of mandibular deciduous and permanent molars in Australian Aborigines. Homo, 55(1-2):53-64, 2004.

Kondo, S.; Townsend, G. C. \& Yamada, H. Sexual dimorphism of cusp dimensions in human maxillary molars. Am. J. Phys. Anthropol., 128(4):870-7, 2005.

Ling, J. Y. \& Wong, R. W. Tanaka-Johnston mixed dentition analysis for southern Chinese in Hong Kong. Angle Orthod., 76(4):632-6, 2006.

Martin de las Heras, S.; Valenzuela, A.; Villanueva, E.; Marques, T.; Exposito, N. \& Bohoyo, J.M. Methods for identification of 28 burn victims following a 1996 bus accident in Spain. J. Forensic Sci., 44(2):428-31, 1999.
Moorrees, C. F. \& Reed, R. B. Correlations among crown diameters of human teeth. Arch. Oral Biol., 115:685-97, 1964.

Nambiar, P.; Jalil, N. \& Singh, B. The dental identification of victims of an aircraft accident in Malaysia. Int. Dent. J., 47(1):9-15, 1997.

Ndiokwelu, E.; Miquel, J. L. \& Coudert, N. Identification of victims of catastrophes: introduction to the role of forensic odontology. Odontostomatol Trop., 26(104):336, 2003.

Petju, M.; Suteerayongprasert, A.; Thongpud, R. \& Hassiri, $\mathrm{K}$. Importance of dental records for victim identification following the Indian Ocean tsunami disaster in Thailand. Public Health, 121(4):251-57, 2007.

Pettenati-Soubayroux, I.; Signoli, M. \& Dutour, O. Sexual dimorphism in teeth: discriminatory effectiveness of permanent lower canine size observed in a XVIII ${ }^{\text {th }}$ century osteological series. Forensic Sci. Int., 126(3):227-32, 2002.

Rodríguez, F. C. D. Antropología dental en Colombia: Comienzos y perspectivas de investigación. Boletín de Antropología de la Universidad de Antioquia, 17(33): 312 28, 2003.

Rodríguez, F. C. D. Dental morphology and biological distances whitin a sonso pre-conquest population from Colombia. Int. J. Dental Anthropol., 5:15-22, 2004.

Ruiz, B. I. Análisis de ancho mesio distal coronario y discrepancias dento-dentarias en pacientes ortodóncicos de la ciudad de Talca. Tesis para Optar al Título de Cirujano Dentista. Universidad de Talca, Chile, 2004

Scott, G. R. \& Turner, C. G., The anthropology of modern human teeth. Cambridge, Cambridge University Press, 1997.

Slaus, M.; Strinovic', D.; Pec'ina-Slaus, N.; Brkic', H.; Balicevic', D.; Petrovecki, V. \& Pec'ina, T. C. Identification and analysis of human remains recovered from wells from the 1991 war in Croatia. Forensic Sci. Int., 171(1):37-43, 2007.

Solheim, T.; Lorentsen, M.; Sundnes, P. K.; Bang, G. \& Bremnes, L. The "Scandinavian Star" ferry disaster 1990-a challenge to forensic odontology. Int. J. Legal Med., 104(6):339-45, 1992. 
SUAZO, G. I.; CANTÍN, L. M; LÓPEZ, F. B.; SANDOVAL, M. C.; TORRES, M. S.; GAJARDO, R. P. \& GAJARDO, R. M. Sexual dimorphism in mesiodistal and bucolingual tooth dimensions in Chilean people. Int. J. Morphol., 26(3):609-614, 2008.

Stanley, H. R.; White, C. L. \& McCray, L. The rate of tertiary (reparative) dentine formation in the human tooth. Oral Surg. Oral Med. Oral Pathol., 21(2):180-9, 1966.

Teschler-Nicola, M. Sexual dimorphism of tooth crown diameters. A contribution to the determination of the sex of subadult individuals from the early bronze age graveyard of Franzhausen I, lower Austria. Anthropol. Anz., 50(1-2):51-65, 1992.

Toribio, S. L. R. \& Soto, I. H. La estomatología forense en situaciones de desastres. Rev. Cubana Estomatol., 32(1):41-4, 1995.

Valenzuela, A.; Martin-de las Heras, S.; Marques, T.; Exposito, N. \& Bohoyo, J. M. The application of dental methods of identification to human burn victims in a mass disaster. Int. J. Legal. Med.,113(4):236-9, 2000.

Van der Kuijl, B. \& Van der Pols, L. C. Forensic odontological identification of disaster victims. Experience with the disaster of the Martinair DC-10 in Faro, Portugal. Ned. Tijdschr. Tandheelkd., 102(6):23642, 1995.

Wood, B. A.; Li, Y. \& Willoughby, C. Intraspecific variation and sexual dimorphism in cranial and dental variables among higher primates and their bearing on the hominid fossil record. J. Anat., 174:185-205, 1991.
Correspondence to:

Prof. Dr. Iván Suazo Galdames

Departamento de Anatomia Normal

Universidad de Talca

Avenida Lircay s/n oficina №104

CHILE

Email: isuazo@utalca.cl

Received: $14-02-2008$

Accepted: 21-06-2008 